\title{
A Tweezer-like Peptide-binding Receptor
}

\author{
Ji Eun Jung and Scung Soo Yoon ${ }^{*}$ \\ Department of Chemisir. SungKyunKwan University; Sinon 410-746, Korea \\ Received Augus/ 8, 2003
}

Key Words : Molecular recognition, Synthetic receptor. Peptide-binding

In recent years, significant progress has been made in the construction of synthetic molecules that selectively bind peptide substrates and other small molecules.' Some such molecules have the complex. cage-like structures, but a dilferent and simple structural motif such as molecular tweczer with two substrate binding arms has emerged as having selective peptide-binding properties. ${ }^{2}$ Among those are 1wo-armed receptors based on cyclic oligomers of 1,2diamine and isophthalic acid. Although such receptors showed remarkable binding properties, to have further possible applications its binding properties had to be improved. Here, a novel two-armed tweezer-like peptidebinding receptor is described.

Receptor (1) consist of two different parts: $\Lambda$ linker to which the tweczer arms are attached; and two substrate binding arms based on cyclic tetramer of two isophthalic acids and two 1,2-diaminocyclohexane. Particularly, linker in receptor (1) has transition metal ion $\left(\mathrm{Ru}^{2}\right)$. In this receptor-like molecule, metal ion acts to make potential substrate-binding sites to be preorganized for the effective complexation with suitable substrates. Furthermore, metal ion such as $\mathrm{Ru}$ can act as the sensitive probes for binding with substrates and provide the additional interactions between linkers and peptide substrates.

Synthesis of 1 began with the preparation of monocyclic intemediates of 1,2-diaminocyclohexanes and isophthalic acid derivatives by the known procedures for the related molccules. " Ester bond formation reaction between bis(pentalluorophenyl)ester (2) and 4,4'-hydroxymethyl-2,2'dipyridine (3) ${ }^{+}$and the subsequent reaction with $\mathrm{Ru}(\mathrm{bpy})_{2} \mathrm{Cl}_{2}$

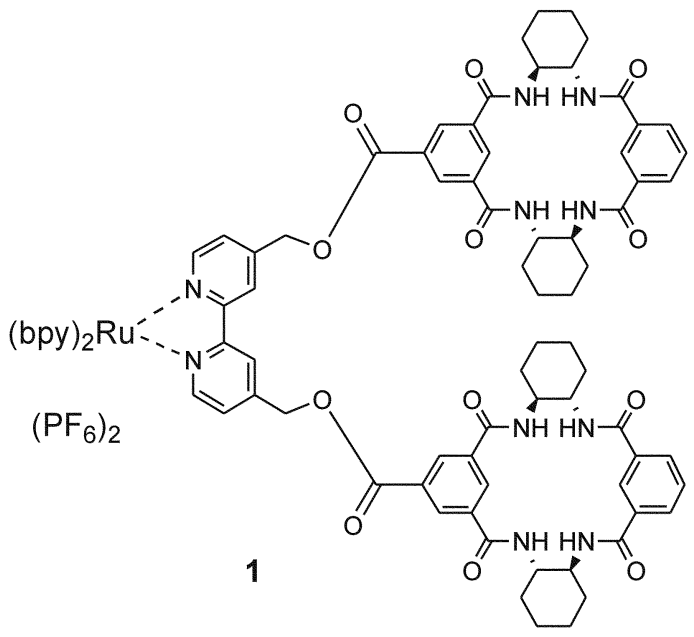

Scheme 1, Two-armed Tiveererlike Receptor (1).

in relluxing E1OI 1 provided 1 with $48.2 \%$ yield.

Recently, combinatorial chemistry has become a major tool in the elucidation of the binding properties of receptors." By using such methods it has become possible to lind the binding properties of receptors elîiciently, and furthermore to detect subtle diflerences in receptor-substrate binding that could not have been studied by conventional experiments.

Receptor 1 has the distinct red color due to transition metal ion (Ru), and thus ideal for solid phase color binding assay using encoded combinatorial library of peptide substrates.

Receptor 1 was screened against a tripeptide library on
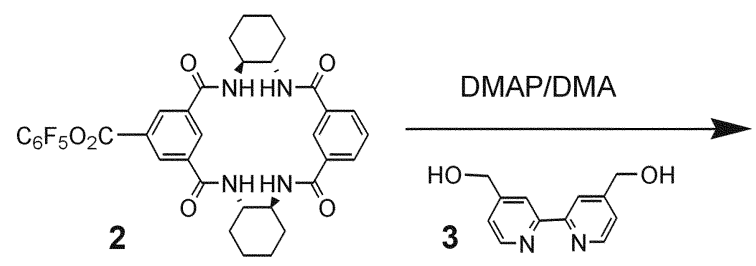

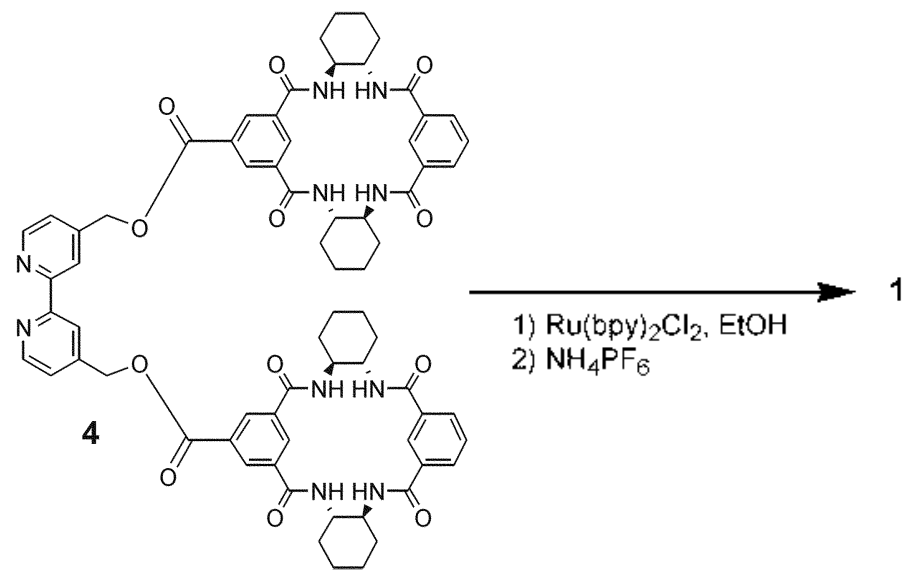

Scheme 2. Synthesis of 1 
Table 1. Sequences selected by binding assay with receptor (1)

\begin{tabular}{llrl}
\hline 1 & (L)Gln-(L)Val-(L)Pro & 8 & (L)Lys-(L)Val-(L)Pro \\
2 & (L)Gln-(L)Val-(L)Pro & 9 & (L)Asn1-(L)Pro-(L)Ser \\
3 & (L)Gln-(L)Pro-(L)Ser & 10 & (L)Asn1-(L)Pro-(L)Pro \\
4 & (L)Asn-(L)Pro-(L)Ser & 11 & (L)Gln-(L)PTo-(L)Pro \\
5 & (L)Gln-(L)Val-(L)Asit & 12 & (L)Lys-(L)Pro-(L)Ser \\
6 & (L)Gln-(L)Val-(L)Pro & 13 & (L)His-(L)Val-(L)Gln \\
7 & (L)Asn-(L)Pro-(L)Gln & 14 & (D)Asn1-(L)Val-(L)Asin \\
\hline
\end{tabular}

hydrophobic polystyrene in $\mathrm{CHCl}_{3}$. The library was prepared by encoded split synthesis and has the general structure Ac-AA3-AA2-AA1- $\mathrm{NH}\left(\mathrm{CH}_{2}\right)_{6}-\mathrm{C}(\mathrm{O}) \mathrm{NH}$-Polystyrene. ${ }^{6}$ Decoding the tripeptides on the colored beads by using electron capture gas chromatography revealed selective peptides- binding properties of molecular tweezer (1). The most tightly binding substrates with 1 are shown in Table 1.

The binding data in Table 1 reveal a number of notable trends. First. high selectivity was observed for the residue in AAl composed of amino acids such as (L)Gln and (L)Asn which have hydrogen bonding domor/acceptors in the side chain. Second. selectivities were also found for AA2 and AA3 position. The substrates with (L)Pro and (L)Val. and (L)Pro at $A A 2$ and $A A 3$ position were found to bind strongly.

To confirm the findings and to estimate the energetic extents of the selectivities observed. the most tightly bound peptide. Resin-(L)Gln-(L)Val-(L)Pro was resynthesized and its associations with 1 measured in $\mathrm{CHCl}_{3}{ }^{7}$ The binding energy was found to be $-4.2 \mathrm{kcal} / \mathrm{mol}$. The other substrates found by binding assay are expected to have the sinuilar range of binding energies. The binding energy between 1 and (L)Gln-(L)Val-Gly, which is not found in assay, were found to be $-2.9 \mathrm{kcal} / \mathrm{mol}$. Thus molecular tweezer (1) shows highly selective and efficient binding properties for certain tripeptides.

In conclusion. metallomolecular tweezer with two substrate binding arms was readily prepared from 1.2-diaminocyclohexane and isophthalic acid. Combinatorial binding assay revealed that this receptor has remarkable sequenceselective tripeptide binding properties.

\section{Experimental Section}

Synthesis of 1 . To a solution of $0.1 \mathrm{~g}$ of $3(0.463 \mathrm{mmol})$ and $0.17 \mathrm{~g}$ of DMAP $(1.37 \mathrm{mmol})$ in $10 \mathrm{~mL}$ of DMA was added $0.71 \mathrm{~g}$ of $2(1.01 \mathrm{mmol})$ at room temperature. After the stirring for $12 \mathrm{hr}$ at room temperature. all volatiles were removed at reduced pressure. The residue was purified by flash cluromatography on silica gel using $10 \% \mathrm{MeOH}$ in methylene chloride to give 4 as an amorphous white solid (0.29 g. $51.0 \%$ ): ${ }^{\mathrm{l}} \mathrm{H} \mathrm{NMR}\left(\mathrm{CDCl}_{3} / \mathrm{CD}_{3} \mathrm{OD}\right) \delta$ (ppm) 1.21 (bs. $4 \mathrm{H}$ ). 1.32 (bs, 2H), 1.59 (bs. 2H). 3.94 (bs, 2H), 4.77 (s, $2 \mathrm{H}) .7 .3 \mathrm{l}(\mathrm{d}, \mathrm{IH} . J=5.0 \mathrm{~Hz}), 8.02(\mathrm{~d} .2 \mathrm{H} . J=6.2 \mathrm{~Hz}), 8.24$ (t. $1 \mathrm{H} . J=6.2 \mathrm{~Hz}) .8 .42(\mathrm{~s} . \mathrm{HH}), 8.52(\mathrm{~s}, 2 \mathrm{H}), 8.62(\mathrm{~s}, \mathrm{lH})$, $8.7 \mathrm{l}$ (d. $1 \mathrm{H}, J=5.0 \mathrm{~Hz}$ ), 8.82 (s. lH): ): MS (FAB) $m z \mathrm{l} 1244$ $\left(\mathrm{MH}^{-}\right)$.

To a solution of $200 \mathrm{mg}$ of $4(0.161 \mathrm{mmol})$ in $10 \mathrm{~mL}$ of ethanol was added $78 \mathrm{mg}$ of $\mathrm{RuCl}_{2}$ (bpy) $2(0.161 \mathrm{mmol}$ ). After stirring for $12 \mathrm{hr}$ under reflux condition. $100 \mathrm{mg}$ of $\mathrm{NH}_{4} \mathrm{PF}_{6}$ was added to precipitate the crude products. The crude products were recrystallized from $\mathrm{MeOH} / \mathrm{ethyl}$ ether to give 1 as an amorphous dark-red solid ( $130 \mathrm{mg}, 48.2 \%$ ): ${ }^{1} \mathrm{H}$ NMR (DMSO-D $) \delta$ (ppm) 1.15 (bs. $4 \mathrm{H}$ ), 1.43 (bs. 2H), 1.69 (bs, 2H). 4.14 (bs. 2H), 4.98 (m, 2H). 7.52 (m. 2H), $7.82(\mathrm{~m}, 2 \mathrm{H}), 8.21-8.43(4 \mathrm{H}) .8 .72-8.80(\mathrm{~m}, 6 \mathrm{H}), 8.88-8.95$ (m. 4H); UV $\left(\mathrm{CHCl}_{3}\right)$ 231. 487. 586 1m: MS (FAB) $\mathrm{mz}$ $1658\left(\mathrm{M}^{-}\right)$

Acknowledgement. This work was supported by Korea Research Foundation (Grant No. 2000-015-DP0262).

\section{References}

1. Still, W. C.Acc. Chem Res. 1996. 29. 155 ; Kim. D.-H.: Choi. M. J. Chang. S.-K. Bull. Konem Chem. Soc. 2001. 22.699.

2. Wennemers. H.: Conza. M.: Nold. M.: Krattiger. P. Chem. Eur. J. 2001. 7.3342 and references therein.

3. Wennemers, H.; Yoon. S. S.: Still, W. C. J. Org Chent 1995, 60. 1108.

4. Oxidation of $4,4^{\prime}$-dimethy-2,2-dipyridine by selenium oxide in diglyme and the subsequent reduction of the resulting dialdehyde by lithium borohydride provided 4 with $83^{\circ} \circ$ yield

5. See the related approach: Ohlmeyer. M. H. L.: Swanson. R. T.: Dillard, L. W.: Reader, J. C.: Asouline, G:; Kobayashi. R: Wigler. M.: Still. W. C. Proc Katl Acad Sa. USt, 1993. 90. 10922: Borchardt, A.; Still. W. C. J. Am. Chem. Soc. 1994. 116. 373. Jung. T. E.: Yoon. S. S. Bull. Kowan Chem. Soc. 2012. 23. 1483: Tung. J. E.: Yoonl. S. S. Bull. Korean Chem. Soc. 2002. 23. 1655.

6. AAn = Any possible combinations of $25(\alpha)$-amino acids such as Gly, (L)Ala. (D)Ala, (L)Val. (D) Val, (L)Leu, (D)Leu. (L)Phe, (D)Phe, (L)Pro. (D)Pro, (L)Ser(OBBu), (D)Ser(OtBu), (L)Asp(OtBu). (D)Asp(OtBu). (L)Glu(OtBu). (D) Glu(OtBu). (L)Astr(Tr). (D) $\mathrm{Asn}(\mathrm{Tr})$. (L) Gln1(Tr). (D)Gln1(Tr). (L)Lys(Boc). (D) Lys $(\mathrm{Boc})$. (L)His(Tr). (D)His(Tr). The number of members in substrates library is $(25)^{3}, 15625$. A total of 15 tag molecules (five tags for AAn) were used to encode the library according to the method reported in wafenuce? 7 .

7. Yoot1. S. S.: Still. W. C. Tetrahedron 1995. 51. 567. 